\title{
PENGARUH PARTISIPASI PEMAKAI SISTEM INFORMASI AKUNTANSI DAN KECANGGIHAN TEKNOLOGI INFORMASI TERHADAP EFEKTIVITAS SISTEM INFORMASI AKUNTANSI DENGAN KEMAMPUAN TEKNIK PERSONAL SEBAGAI VARIABEL PEMODERASI PADA LEMBAGA PERKREDITAN DESA (LPD) DI KECAMATAN SUKAWATI
}

\author{
I Putu Deddy Samtika Putra ${ }^{1)}$ \\ Sang Ayu Putu Arie Indraswarawati ${ }^{2)}$ \\ 1),2) Universitas Hindu Indonesia, email: deddy.samtika@gmail.com
}

\begin{abstract}
The accounting information system effectiveness is a success achieved by accounting information system in generating information in a timely and accurate. The success of accounting information system is supported by several factors, namely the user participation of accounting information system the technology sophistication information and personal technical capability. This study aims to determine the effect of user participation of accounting information system and the technology sophistication information to the accounting information system effectiveness with personal technical capability as variable of moderate. The research was conducted on the LPD in district Sukawati.

The population in this research is all LPD employees in district Sukawati amounting to 267 employees from 33 LPD. The sampling technique used is the purposive sampling method, in order to obtain a sample of 111 people from 23 LPD. Data collection by using a survey method, wich is spread questionnaire. The analytical techniques used is Moderated Regression analysis (MRA).

Based on the results of the hypothesis testing suggests that the user participation of accounting information system has no significant effect on the accounting information system effectiveness, with parameter coefficient value of 0.003 with significance of $0.986>$ 0.05. The technology sophistication information positively and significantly affects the accounting information system effectiveness, with a parameter coefficient value of 0.452 with significance of $0.002<0.05$. Personal technical capability does not moderate the influence of the user participation of accounting information system to the accounting information system effectiveness, with a parameter coefficient value of -0.004 with significance of $0.938>0.05$. The ability of personal technical capability does not moderate the influence of the technology sophistication information to the accounting information system effectiveness, with a parameter coefficient value of -0.007 with significance of 0.893 $>0.05$.
\end{abstract}

Keywords: User participation of accounting information system, technology sophistication information, personal technical capability and accounting information system effectiveness. 


\section{PENDAHULUAN}

Pada era globalisasi saat ini menimbulkan persaingan yang semakin ketat antar perusahaan yang medorong setiap perusahaan untuk menerapkan sistem informasi yang dapat mendukung kemampuan operasional perusahaan secara efektif, efisien dan terkendali sehingga mampu melahirkan keunggulan yang kompetitif. Pengguna sistem yang terkomputerisasi dalam pengolahan data perusahaan merupakan wujud dari perkembangan teknologi dan informasi yang begitu pesat. Hal ini digunakan untuk menunjang kegiatan operasional dalam rangka menghasilkan keputusan yang tepat dan bermanfaat bagi perusahaan.

Sistem informasi akuntansi merupakan komponen-komponen yang saling berhubungan untuk mengumpulkan, menyimpan, mengolah dan menyebarkan informasi untuk tujuan perencanaan, pengendalian, koordinasi, analisis dan pengambilan keputusan (Soudani, 2012). Sistem menjalankan perannya yaitu dengan memproses data dan mengubahnya menjadi suatu informasi akuntansi yang memiliki nilai tambah dan kemudian digunakan oleh berbagai pengguna internal dan pengguna eksternal dalam pengambilan keputusan (Onaolapo dan Odetayo, 2012). Fungsi utama sistem informasi akuntansi adalah mengolah data dari transaksi keuangan menjadi informasi yang bermanfaat bagi perusahaan. Wilayanti (2016) mengungkapkan bahwa sistem informasi akuntansi berperan penting dalam proses pengambilan keputusan yang efektif untuk mengendalikan dan mengkoordinasikan kegiatan organisasi sehingga dapat mencapai kinerja yang lebih baik. Pentingnya penggunaan sistem informasi akuntansi dalam menghasilan informasi yang berkualitas dan mendukung proses pengambilan keputusan sehingga dapat meningkatkan efisiensi organisasi.

Fenomena mengenai kurang efektifnya sistem informasi akuntansi dapat dilihat dari kasus terjadi pada LPD Berangbang yang berlokasi di Kecamatan Negara, Kabupaten Jembrana. LPD Berangbang dalam pengolahan datanya menggunakan program Microsoft Excel. Dimana program tersebut dirasa masih memiliki kelemahan, karena dalam pengolahan data akuntansi tidak secara otomatis. Data yang di input dengan program Microsoft Excel harus diolah sendiri oleh karyawan untuk dapat menghasilkan laporan keuangan yang dibutuhkan. Hal ini menyebabkan proses data keuangan LPD mejadi terhambat dan data yang tercantum dalam laporan keuangan masih diragukan tingkat keakuratannya (media.neliti.com, 2015). 
Kasus kurang efektifnya sistem informasi akuntansi juga terjadi pada LPD Desa Adat Lungsiakan, Kabupaten Gianyar. Berdasarkan hasil observasi yang dilakukan oleh Lisnawati (2017), pada tahun 2017 LPD Desa Adat Lungsiakan pernah dua kali mengalami keterlambatan dalam melaporkan laporan keuangan tiap bulannya kepada LPLPD Kabupaten Gianyar. I Wayan Darsa selaku ketua LPD menyatakan bahwa hal ini terjadi karena faktor sumber daya manusia LPD yang masih kurang menguasai dalam pengoperasian SIA. Kurang canggihnya sistem informasi akuntansi yang terinstal pada LPD menyebabkan proses manual masih diterapkan.

Partisipasi pemakai sistem informasi akuntansi merupakan aktivitas personal dalam tahap pengembangan sistem informasi akuntansi yang menunjukkan seberapa besar tingkat keterlibatan responden terhadap proses pengembangan sistem informasi akuntansi (Kharisma, 2015). Partisipasi dapat meningkatkan kepuasan pemakai dalam menggunakan sistem informasi untuk menghasilkan informasi yang sesuai dengan kebutuhannya. Apabila pemakai diberikan kesempatan untuk ikut berpartisipasi dalam pengembangan sistem informasi maka pemakai akan merasa bahwa sistem informasi merupakan tanggungjawabnya, sehingga sistem informasi menjadi semakin efektif.

Ketidakkonsistenan hasil dari penelitian sebelumnya diduga karena adanya faktor lain yang dapat memperkuat maupun memperlemah pengaruh partisipasi pemakai sistem informasi akuntansi dan kecanggihan teknologi informasi dengan efektivitas sistem informasi akuntansi. Maka, pada penelitian ini menggunakan kemampuan teknik personal sebagai variabel pemoderasi. Sistem informasi akuntansi yang efektif membutuhkan adanya pemakai sistem informasi yang memiliki kemampuan yang tinggi. Kemampuan teknik personal pemakai dalam mengoperasikan suatu sistem informasi akuntansi sangat dibutuhkan, agar dapat mengoperasikan suatu sistem secara maksimal dan mengurangi terjadinya kesalahan maupun kegagalan dalam pengoperasian sistem informasi.

LPD di Kecamatan sukawati merupakan lembaga keuangan yang telah menerapkan sistem informasi akuntansi berbasis komputer dalam pengolahan data keuangan. Seperti yang diketahui tingkat pariwisata di Kecamatan Sukawati yang mulai mengalami peningkatan, dimana Sukawati memiliki banyak potensi alam dan seni yang baik untuk dikembangkan. Untuk mengembangkan potensi tersebut, LPD sebagai lembaga keuangan yang berfungsi menyalurkan dana kepada masyarakat sangat diperlukan untuk pendanaan dalam mengembangkan potensi tersebut. Dalam menunjang aktivitas LPD penerapan suatu 


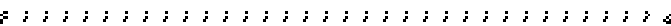

: Widya Akuntansi dan Keuangan

: Universitas Hindu Indonesia

- Edisi Agustus 2020

sistem informasi akuntansi yang efektif sangat diperlukan untuk meningkatkan pelayanan serta untuk memproses data transaksi yang lebih cepat, akurat dan tepat waktu, sehingga diharapkan LPD mampu bersaing dengan lembaga keuangan lainnya.

Berdasarkan uraian latar belakang diatas maka penelitian ini bertujuan untuk menganalisis Pengaruh Partisipasi Pemakai Sistem Informasi Akuntansi dan Kecanggihan Teknologi Informasi Terhadap Efektivitas Sistem Informasi Akuntansi dengan Kemampuan Teknik Personal sebagai Variabel Pemoderasi Pada Lembaga Perkreditan Desa (LPD) di Kecamatan Sukawati.

Teori dasar yang digunakan dalam penelitian ini adalah Teori Technology Acceptance Model (TAM) yang merupakan suatu teori mengenai sistem informasi yang memuat model mengenai sikap individu untuk menerima dan menggunakan teknologi. TAM merupakan salah satu model yang dibangun untuk menganalisis dan memahami faktor-faktor yang mempengaruhi diterimanya penggunaan teknologi komputer yang perkenalkan pertama kali oleh Fred Davis pada tahun 1989. Berdasarkan teori ini menggambarkan bahwa kemudahan berhubungan dengan kemampuan teknik personal yang dimiliki oleh para pemakai sistem informasi, adanya kemampuan teknik personal akan memudahkan individu dalam menggunakan suatu sistem informasi, dan akan semakin meningkatkan kepuasan pemakai dalam menggunakan suatu sistem informasi akuntansi, sehingga dapat memberikan pengaruh yang baik bagi perusahaan dan dapat meningkatkan partisipasi pemakai dalam pengembangan sistem informasi akuntansi.

Sistem adalah suatu rangkaian yang terdiri dari bagian-bagian yang saling terkait dan mempengaruhi yang digunakan untuk mencapai tujuan tertentu. Definisi sistem menurut Mulyadi (2016:2). Informasi merupakan sebuah data yang telah diolah menjadi bentuk yang lebih berarti bagi penerimanya dan dapat digunakan sebagai alat pembuat keputusan (Bodnar dan William, 2005).

Sistem informasi adalah sekumpulan komponen yang saling berhubungan, mengumpulkan, memproses, menyimpan dan mendistribusikan informasi untuk menunjang pengambilan keputusan dan pengawasan dalam suatu organisasi. (Sari, 2008). Tujuan sistem informasi akuntansi adalah untuk menyajikan informasi akuntansi kepada berbagai pihak yang membutuhkan informasi tersebut baik pihak internal maupun eksternal.

Sistem informasi yang baik diharapkan dalam pelaksanaannya menghasilkan informasi-informasi yang berkualitas dan bermanfaat bagi pengguna informasi baik internal 


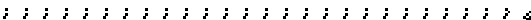

: Widya Akuntansi dan Keuangan

: Universitas Hindu Indonesia

Edisi Agustus 2020

maupun eksternal yang di nantinya digunakan dalam pengambilan keputusan. Sistem informasi yang baik dirancang untuk dapat menghasilkan informasi yang tepat waktu, relevan dan dipercaya. Secara umum sistem informasi akuntansi berbasis komputer adalah sistem informasi yang menggunakan teknologi komputer dalam mengelola data atau transaksi perusahaan menjadi suatu informasi yang tepat, akurat, dan relevan dalam pengambilan keputusan.

Efektivitas sistem informasi akuntansi merupakan suatu ukuran yang memberikan gambaran sejauh mana target dapat dicapai dari suatu kumpulan sumber daya yang diatur untuk mengumpulkan, memproses dan menyimpan data, kemudian mengubahnya menjadi sebuah informasi yang berguna serta menyediakan laporan formal yang dibutuhkan dengan baik secara kualitas maupun waktu (Damayanthi, 2012). Terry (2004) mengungkapkan bahwa dengan adanya dukungan dari partisipasi pemakai akan meningkatkan kepuasan pemakai itu sendiri. Partisipasi pemakai digunakan untuk menunjukkan intervensi personal yang nyata pemakai dalam pengembangan sistem informasi, mulai dari tahap perencanaan, pengembangan sampai implementasi sistem informasi akuntansi.

Menurut Robbins (2005:45) kemampuan teknik personal adalah kapasitas seseorang untuk melaksanakan berbagai tugas dalam pekerjaan tertentu. Kemampuan teknik personal sangat dibutuhkan, dimana kemampuan teknik personal akan menunjukkan sejauh mana kualitas pribadi seseorang dalam menguasai teknik pengelolaan sistem informasi akuntansi yang dikembangkan.

Hipotesis dalam penelitian ini adalah:

H1 : Partisipasi pemakai sistem informasi akuntansi berpengaruh terhadap efektivitas sistem informasi akuntansi.

H2: Kecanggihan Teknologi Informasi berpengaruh terhadap efektivitas sistem informasi akuntansi.

H3 : Kemampuan teknik personal mampu memoderasi pengaruh partisipasi pemakai sistem informasi akuntansi terhadap efektivitas sistem informasi akuntansi.

H4 : Kemampuan teknik personal mampu memoderasi pengaruh kecanggihan teknologi informasi terhadap efektivitas sistesm informasi akuntansi. 


\section{METODE PENELITIAN}

Partisipasi pemakai sistem informasi dalam pengembangan sistem informasi akuntansi berperan penting dalam mencapai kesuksesan penerapan sebuah sistem. Partisipasi pemakai sistem informasi akuntansi merupakan keterlibatan pengguna sistem informasi dalam melakukan aktivitas yang berkaitan dengan sistem informasi untuk memberikan dukungan dan kontribusi dalam proses perencanaan, pengembangan dan implementasi sistem informasi akuntansi (Wilayanti, 2016). Efektivitas sistem informasi akuntansi juga dipengaruhi oleh kecanggihan teknologi informasi. Kecanggihan teknologi informasi adalah teknologi yang terkomputerisasi dan terintegritas yang didukung oleh aplikasi pendukung modern yang diharapkan dapat memberikan dampak positif bagi kelangsungan kinerja karyawan (Ratnaningsih, 2014). Kecanggihan teknologi informasi dalam perusahaan akan memudahkan pemakai sistem dalam memproses data keuangan perusahaan sehingga dapat menghasilkan informasi yang berkualitas dan tepat waktu untuk pengambilan keputusan yang efektif.

Sistem informasi akuntansi tidak akan berjalan efektif apabila tidak didukung dengan adanya kemampuan teknik personal dari pemakai sistem informasi akuntansi. Kemampuan teknik personal merupakan kemampuan dalam diri seseorang berdasarkan atas pengalaman serta pendidikan dan pelatihan yang pernah diikuti sehingga dapat meningkatkan kepuasan dalam menggunakan sistem informasi akuntansi yang diterapkan oleh suatu organisasi (Kameswara, 2013). Berdasarkan uraian yang telah dipaparkan, maka kerangka pemikiran dalam penelitian ini dapat digambarkan sebagai berikut:

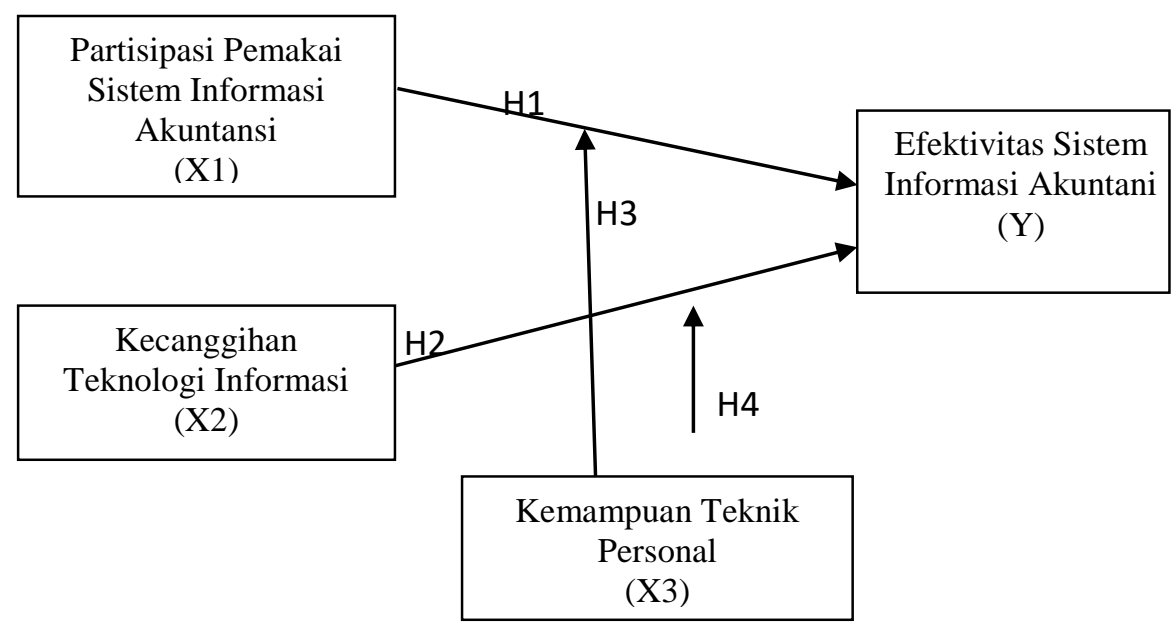

Gambar 1 : Kerangka Pemikiran 
Populasi dalam penelitian ini adalah seluruh karyawan Lembaga Perkreditan Desa di Kecamatan Sukawati sehingga jumlah populasi dalam penelitian ini adalah 267 orang karyawan dari 33 Lembaga Perkreditan Desa (LPD) di Kecamatan Sukawati. Sampel dalam penelitian ini diambil menggunakan teknik purposive sampling. Purposive sampling adalah teknik penentuan sampel dengan pertimbangan tertentu, dimana anggota sampel akan dipilih sedemikian rupa sehingga sampel yang dibentuk tersebut dapat mewakili sifat-sifat populasi (Sugiyono, 2017:85)

Kriteria dalam pengambilan sampel dalam penelitian ini adalah sebagai berikut: (1) LPD yang memiliki aset lebih besar atau sama dengan Rp. 3.000.000.000, (2) LPD yang telah menggunakan sistem informasi akuntansi dengan program aplikasi dalam pengolahan data lebih dari satu tahun dengan pertimbangan bahwa LPD tersebut telah mengetahui dan memahami sistem informasi akuntansi. Berdasarkan dari hasil perhitungan penentuan jumlah sampel penelitian yang digunakan menjadi sampel adalah 23 LPD dengan responden pada masing-masing LPD yaitu kepala LPD, karyawan pada bagian tata usaha, karyawan pada bagian bendahara/ kasir dan karyawan pada bagian kredit.

Model regresi dalam penelitian ini ditunjukkan dengan persamaan sebagai berikut: $Y=\alpha+\beta_{1} X_{1}+\beta_{2} X_{2}+\beta_{3} X 3+\beta_{4} X 1 . X_{3}+\beta_{5} X_{2} X_{3}+e$

Keterangan:

Y

$\alpha$

$\beta_{1}-\beta_{5}$

$\mathrm{X} 1$

$\mathrm{X} 2$

$\mathrm{X} 3$

$\mathrm{X} 1 . \mathrm{X} 3$

$\mathrm{X} 2 . \mathrm{X} 3$

e
$=$ Efektivitas Sistem Informasi Akuntansi

$=$ Konstanta

$=$ Koefisien regresi masing-masing variabel independen

$=$ Partisipasi pemakai sitem informasi akuntansi

$=$ Kecanggihan teknologi informasi

$=$ Kemampuan teknik personal

$=$ Interaksi antara patisipasi pemakai sistem infomasi akuntansi dengan kemampuan teknik personal

$=$ Interaksi antara kecanggihan teknologi informasi dengan kemampuan teknik personal

$=$ error, yaitu tingkat kesalahan pendugaan dalam penelitian 


\section{HASIL PENELITIAN}

Data dikumpulkan dengan menyebarkan kuesioner ke Lembaga Perkreditan Desa di Kecamatan Sukawati yang memenuhi kriteria sampel. Kuesioner disebarkan berjumlah 111 kuesioner dan disebar di 23 LPD di Kecamatan Sukawati. Kuesioner yang kembali adalah sebanyak 107 kuesioner. Jumlah kuesioner yang disebarkan ke responden sebanyak 111 (100\%) kuesioner. Dari 111 kuesioner yang disebar, tidak seluruhnya diisi oleh responden dan dikembalikan kepada peneliti. Hanya 107 (96,40\%) kuesioner yang kembali dan dapat diolah.

Pengujian validitas dapat dilakukan dengan menghitung korelasi antara skor masingmasing butir pernyataan dengan total skor sehingga didapat nilai pearson correlation. Suatu instrumen dikatakan valid jika nilai $\mathrm{r}$ pearson correlation terhadap skor total di atas 0,30 (Sugiyono, 2014:178). Hasil uji validitas dalam penelitian ini bahwa semua variabel dalam penelitian ini dinyatakan valid.

Uji reliabilitas digunakan untuk menunjukkan sejauh mana pernyataan kuesioner relatif konsisten apabila kuesioner tersebut digunakan dari waktu ke waktu (Ghozali (2013:172). Uji reliabilitas dilakukan kepada 107 orang responden dengan menghitung cronbach alpha dari masing-masing item dalam suatu variabel. Item-item pernyataan dapat dikatakan reliabel apabila memiliki nilai cronhbach alpha lebih dari 0,6, maka disimpulkan bahwa instrumen penelitian tersebut reliabel.

Statistik deskriptif dalam penelitian ini disajikan untuk memberikan informasi mengenai karakteristik variabel-variabel penelitian, antara lain minimum, maksimun, nilai rata-rata (mean) dan standar deviasi. Pengukuran rata-rata (mean) merupakan cara yang paling umum digunakan untuk mengukur nilai sentral dari suatu distribusi data. Hasil statistik deskriptif dapat dilihat pada Tabel 1 berikut:

Tabel 1 Hasil Statistik Deskriptif

\begin{tabular}{|c|l|l|l|l|l|}
\hline Variabel & \multicolumn{1}{|c|}{$\mathrm{N}$} & Minimum & Maximum & Mean & Std. Deviation \\
& & & & & \\
\hline X1 & 107 & 13.00 & 20.00 & 17.1495 & 1.73098 \\
X2 & 107 & 21.00 & 30.00 & 25.9159 & 2.23658 \\
X3 & 107 & 16.00 & 30.00 & 24.0561 & 2.43338 \\
Y & 107 & 27.00 & 40.00 & 35.1495 & 2.95502 \\
Valid N (listwise) & 107 & & & & \\
\hline
\end{tabular}

Sumber: Data Diolah 
Pengujian non-respon bias dilakukan untuk melihat apakah ada perbedaan karakteristik jawaban yang diberikan oleh responden yang membalas kuisioner dengan responden yang tidak membalas kuisioner. Mengingat adanya keterbatasan informasi yang diperoleh peneliti terhadap identitas individu responden yang tidak mengirim jawaban maka dalam penelitian ini responden yang mengembalikan jawaban melewati waktu yang telah ditentukan dianggap mewakili jawaban responden yang tidak merespon. Hasil uji nonrespon bias dapat dilihat pada Tabel 2 berikut:

Tabel 2 Hasil Uji Non Respon Bias

\begin{tabular}{|c|c|c|c|c|c|c|c|c|}
\hline & \multicolumn{5}{|c|}{ Paired Differences } & \multirow[t]{3}{*}{$\mathrm{t}$} & \multirow[t]{3}{*}{ Df } & \multirow{3}{*}{$\begin{array}{c}\text { Sig. } \\
\text { (2-tailed) }\end{array}$} \\
\hline & \multirow[t]{2}{*}{ Mean } & \multirow[t]{2}{*}{$\begin{array}{c}\text { Std. } \\
\text { Deviation }\end{array}$} & \multirow[t]{2}{*}{$\begin{array}{c}\text { Std. Error } \\
\text { Mean }\end{array}$} & \multicolumn{2}{|c|}{$\begin{array}{c}95 \% \text { Confidence Interval } \\
\text { of the Difference }\end{array}$} & & & \\
\hline & & & & Lower & Upper & & & \\
\hline Pair 1 & -.80000 & 2.17781 & .56231 & -2.00603 & .40603 & -1.423 & 14 & .177 \\
\hline Pair 2 & -.73333 & 4.02611 & 1.03954 & -2.96292 & 1.49625 & -.705 & 14 & 492 \\
\hline Pair 3 & -1.13333 & 2.66905 & 68914 & -2.61140 & .34474 & -1.645 & 14 & .122 \\
\hline Pair 4 & -1.00000 & 3.52542 & .91026 & -2.95231 & .95231 & -1.099 & 14 & 290 \\
\hline
\end{tabular}

\section{Sumber: Data Diolah}

Tahap selanjutnya dilakukan uji asumsi klasik terhadap data penelitian agar dapat dianalisis lebih lanjut. Berikut ini hasil uji asumsi klasik yang meliputi uji normalitas, uji multikolinearitas dan uji heterokedastisitas.Uji normalitas dilakukan dengan menggunakan uji statistik Kolgomorov-Smirnov yang biasa disebut dengan K-S yang tersedia dalam program SPSS 21 For Windows. Kriteria yang digunakan adalah dengan membandingkan antara tingkat signifikansi yang didapat dengan tingkat alpha yang digunakan, dimana data dapat dikatakan berdistribusi normal apabila sig. > 0,05 (Ghozali, 2013:160). Hasil uji normalitas dapat dilihat pada Tabel 3 berikut:

Tabel 3 Hasil Uji Normalitas

\begin{tabular}{|c|c|c|}
\hline & & Unstandardized Residual \\
\hline $\begin{array}{l}\text { N } \\
\text { Normal Parameters }{ }^{a, b} \\
\text { Most Extreme } \\
\text { Differences } \\
\text { Kolmogorov-Smirnov Z } \\
\text { Asymp. Sig. (2-tailed) }\end{array}$ & $\begin{array}{l}\text { Mean } \\
\text { Std. Deviation } \\
\text { Absolute } \\
\text { Positive } \\
\text { Negative }\end{array}$ & $\begin{array}{l}106 \\
0 \mathrm{E}-7 \\
2.90388632 \\
.067 \\
.052 \\
-.067 \\
.694 \\
.721\end{array}$ \\
\hline
\end{tabular}

\section{Sumber: Data Diolah}


Berdasarkan Tabel 3 dapat dilihat bahwa hasil uji statistik terlihat nilai signifikansi dari unstandardized residual lebih besar dari 0,05 yaitu sebesar 0,721 sehingga dapat disimpulkan data yang digunakan dalam penelitian ini terdistribusi normal.

Dalam penelitian ini untuk mendeteksi ada atau tidaknya multikolinearitas dengan menganalisis matrik korelasi antar variabel independen dan perhitungan nilai tolerance dan variance inflation factor (VIF). Jika nilai tolerance lebih dari 0,10 dan variance inflation factor (VIF) kurang dari dari 10 maka dikatakan tidak ada multikolinearitas (Ghozali, 2013:105). Hasil uji multikolinearitas dengan menggunakan program SPSS dapat dilihat pada Tabel 4 berikut:

Tabel 4 Hasil Uji Multikolinearitas Sebelum Transformasi Data

\begin{tabular}{|c|c|c|c|c|c|c|c|}
\hline \multirow[t]{2}{*}{ Model } & \multicolumn{2}{|c|}{$\begin{array}{l}\text { Unstandardized } \\
\text { Coefficients }\end{array}$} & \multirow{2}{*}{$\begin{array}{c}\begin{array}{c}\text { Standardized } \\
\text { Coefficients }\end{array} \\
\text { Beta }\end{array}$} & \multirow[t]{2}{*}{$\mathrm{T}$} & \multirow[t]{2}{*}{ Sig. } & \multicolumn{2}{|c|}{ Collinearity Statistics } \\
\hline & $B$ & $\begin{array}{l}\text { Std. } \\
\text { Error }\end{array}$ & & & & Tolerance & VIF \\
\hline (Constant) & 62.630 & 21.263 & & 2.945 & .004 & & \\
\hline $\mathrm{X} 1$ & 3.202 & 2.410 & 1.875 & 1.328 & .187 & .003 & 363.845 \\
\hline $\mathrm{X} 2$ & -3.555 & 1.877 & -2.691 & -1.894 & .061 & .003 & 368.297 \\
\hline X3 & -1.695 & .862 & -1.396 & -1.967 & .052 & .011 & 91.914 \\
\hline $\mathrm{X} 1 \mathrm{X3}$ & -.135 & .102 & -3.416 & -1.314 & .192 & .001 & 1233.032 \\
\hline$\times 2 \times 3$ & .170 & .079 & 6.021 & 2.141 & .035 & .001 & 1442.961 \\
\hline
\end{tabular}

a. Dependent Variable: $Y$

\section{Sumber: Data Diolah}

Berdasarkan Tabel 4, hasil pengujian yang ditunjukkan uji multikolinearitas, nilai tolerance semua variabel lebih kecil dari $0,10 \quad(X 1=0.003 ; \quad X 2=0.003 ; \quad X 3=0.011$; $\mathrm{X} 1 \mathrm{X} 3=0.001 ; \mathrm{X} 2 \mathrm{X} 3=0.001)$ dan nilai VIF lebih besar dari $10(\mathrm{X} 1=363.845 ; \mathrm{X} 2=368.297$; $\mathrm{X} 3=91.914 ; \mathrm{X} 1 \mathrm{X} 3=1233.032 ; \mathrm{X} 2 \mathrm{X} 3=1442.961)$ yang berarti terdapat multikolinearitas antar variabel independen, sehingga dilakukan transformasi data terlebih dahulu sebelum data digunakan pada model regresi. Metode transformasi yang digunakan adalah First Difference. 
Tabel 5 Hasil Uji Multikolinearitas Setelah Transformasi Data

\begin{tabular}{|c|c|c|c|c|c|c|c|}
\hline \multirow[t]{2}{*}{ Model } & \multicolumn{2}{|c|}{$\begin{array}{l}\text { Unstandardized } \\
\text { Coefficients }\end{array}$} & \multirow{2}{*}{$\begin{array}{c}\begin{array}{c}\text { Standardized } \\
\text { Coefficients }\end{array} \\
\text { Beta }\end{array}$} & \multirow[t]{2}{*}{$\mathrm{t}$} & \multirow[t]{2}{*}{ Sig. } & \multicolumn{2}{|c|}{ Collinearity Statistics } \\
\hline & $B$ & Std. Error & & & & Tolerance & VIF \\
\hline (Constant) & .046 & 321 & & .144 & .886 & & \\
\hline $\mathrm{FdX1}$ & .003 & .181 & .002 & .017 & .986 & 419 & 2.387 \\
\hline $\mathrm{FdX} 2$ & .452 & .142 & .364 & 3.176 & .002 & 478 & 2.093 \\
\hline $\mathrm{FdX3}$ & .387 & .132 & .324 & 2.934 & .004 & .514 & 1.945 \\
\hline $\mathrm{FdX} 1 \mathrm{X} 3$ & -.004 & .057 & -013 & -.078 & .938 & 227 & 4.411 \\
\hline $\mathrm{Fd} \times 2 \times 3$ & -.007 & .051 & -022 & -.135 & .893 & 240 & 4.173 \\
\hline
\end{tabular}

a. Dependent Variable: FdY

\section{Sumber: Data Diolah}

Berdasarkan Tabel 5 hasil pengujian yang ditunjukkan uji multikolinearitas, nilai tolerance semua variabel lebih besar dari $0,10 \quad(X 1=0.419 ; \quad X 2=0.478 ; \quad X 3=0.514$; $\mathrm{X} 1 \mathrm{X} 3=0.227 ; \mathrm{X} 2 \mathrm{X} 3=0.240)$ dan nilai VIF lebih kecil dari 10 (X1=2.387; X2=2.093; $\mathrm{X} 3=1.945 ; \mathrm{X} 1 \mathrm{X} 3=4.411 ; \mathrm{X} 2 \mathrm{X} 3=4.173$ ) yang berarti tidak terdapat multikolinearitas antar variabel independen.

Uji heteroskedastisitas dalam penelitian ini dilakukan dengan uji glejser. Jika variabel bebas tidak berpengaruh pada variabel terikat maka tidak terjadi heteroskedastisitas. Suatu model regresi tidak mengandung adanya heterokedastisitas bila nilai signifikan variabel bebas terhadap nilai absolute residual statistik lebih besar $\alpha=0,05$ (Ghozali, 2013:139). Hasil uji heterokedastisitas dapat dilihat pada Tabel 6 berikut:

Tabel 6 Hasil Uji Heteroskedastisitas

\begin{tabular}{|c|c|c|c|c|c|c|}
\hline \multirow[t]{2}{*}{ Moc } & & \multicolumn{2}{|c|}{ Unstandardized Coefficients } & \multirow{2}{*}{$\begin{array}{c}\begin{array}{c}\text { Standardized } \\
\text { Coefficients }\end{array} \\
\text { Beta } \\
\end{array}$} & \multirow[t]{2}{*}{$\mathrm{t}$} & \multirow[t]{2}{*}{ Sig. } \\
\hline & & $\mathrm{B}$ & Std. Error & & & \\
\hline \multirow{6}{*}{1} & (Constant) & 2.172 & .198 & & 10.944 & .000 \\
\hline & $\mathrm{FdX} 1$ & -.081 & .112 & -.111 & -.726 & .470 \\
\hline & $\mathrm{FdX} 2$ & .046 & .088 & .074 & .517 & .607 \\
\hline & $\mathrm{FdX3}$ & .022 & .082 & .036 & .263 & .793 \\
\hline & $\mathrm{FdX} 1 \mathrm{X} 3$ & .047 & .035 & .279 & 1.346 & .181 \\
\hline & $\mathrm{FdX} 2 \times 3$ & -.029 & .031 & -.189 & -.938 & .351 \\
\hline
\end{tabular}

a. Dependent Variable: Abs_Ut

\section{Sumber: Data Diolah}

Berdasarkan Tabel 6 dapat dilihat bahwa pada hasil uji statistik terlihat bahwa seluruh variabel bebas memiliki signifikansi lebih besar dari 0,05 atau sebesar X1=0.470; $\mathrm{X} 2=0.607 ; \mathrm{X} 3=0.793 ; \mathrm{X} 1 \mathrm{X} 3=0.181 ; \mathrm{X} 2 \mathrm{X} 3=0.351$ sehingga dapat disimpulkan bahwa 
model regresi yang digunakan dalam penelitian ini sudah tidak mengandung heteroskedastisitas.

Tabel 7 Hasil Pengujian Moderated Regression Analysis (MRA)

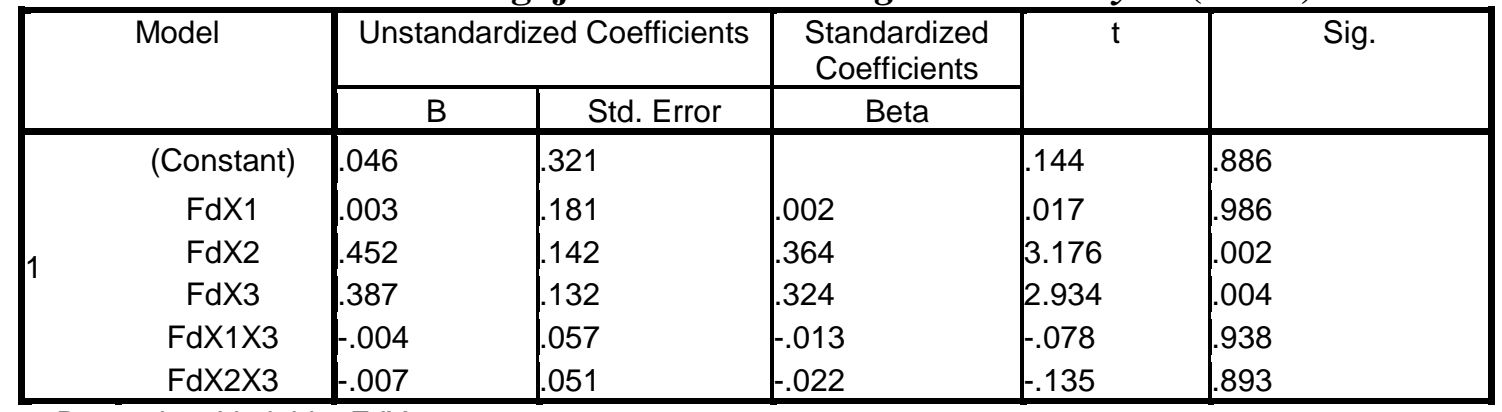

\section{Sumber: Data Diolah}

Berdasarkan Tabel 7 dapat dibuat suatu model persamaan regresi yaitu sebagai berikut: $Y=0.046+0.003 X_{1}+0.452 X_{2}+0.387 X_{3}-0.004 X_{1} X_{3}-0.007 X_{2} X_{3}$

Dari hasil regresi dapat diketahui angka angka Adjusted $R$-Square menunjukkan koefisien determinasi atau peranan variance (variabel independen dalam hubungan dengan variabel dependen). Angka Adjusted R-Square sebesar 0.340 menunjukkan bahwa 34\% variabel independen dijelaskan oleh variabel dependen, sedangkan sisanya sebesar $66 \%$ dijelaskan oleh variabel atau faktor lain.

Uji kelayakan model (Uji F) bertujuan untuk menguji apakah semua variabel bebas berpengaruh terhadap variabel terikat dan untuk mengetahui model regresi yang digunakan dalam penelitian ini layak uji atau tidak (Ghozali, 2013:98). Uji F dilakukan dengan melihat nilai signifikansi pada tabel ANOVA. Apabila nilai signifikansi ANOVA $<\alpha=0,05$, maka model dalam penelitian ini dikatakan layak. Hasil uji F dapat dilihat pada Tabel 8 berikut:

Tabel 8 Hasil Uji Kelayakan Model (Uji F)

\begin{tabular}{|l|l|l|l|l|l|l|}
\hline Model & Sum of Squares & Df & Mean Square & F & Sig. \\
\hline \multirow{4}{*}{1} & Regression & 522.582 & 5 & 104.516 & 11.804 & $.000^{\mathrm{b}}$ \\
Residual & 885.418 & 100 & 8.854 & & \\
Total & 1408.000 & 105 & & & \\
\hline
\end{tabular}

a. Dependent Variable: FdY

b. Predictors: (Constant), FdX2X3, FdX2, FdX3, FdX1, FdX1X3

\section{Sumber: Data Diolah}

Uji t digunakan untuk mengetahui apakah secara langsung variabel independen berpengaruh terhadap variabel dependen secara signifikan atau tidak (Ghozali, 2013:98). Hasil uji t dapat dilihat pada Tabel 9 berikut: 
jajisijijic

: Widya Akuntansi dan Keuangan

: Universitas Hindu Indonesia

Edisi Agustus 2020

Tabel 9 Hasil Uji Hipotesis (Uji t)

\begin{tabular}{|c|c|c|c|c|c|c|}
\hline & \multirow[t]{2}{*}{ Model } & \multicolumn{2}{|c|}{ Unstandardized Coefficients } & \multirow{2}{*}{$\begin{array}{c}\text { Standardized } \\
\text { Coefficients }\end{array}$} & \multirow[t]{2}{*}{$\mathrm{t}$} & \multirow[t]{2}{*}{ Sig. } \\
\hline & & $B$ & Std. Error & & & \\
\hline \multirow{6}{*}{1} & (Constant) & .046 & .321 & & .144 & .886 \\
\hline & $\mathrm{FdX} 1$ & .003 & .181 & .002 & .017 & .986 \\
\hline & $\mathrm{FdX} 2$ & .452 & .142 & 364 & 3.176 & .002 \\
\hline & $\mathrm{FdX} 3$ & .387 & .132 & .324 & 2.934 & .004 \\
\hline & $\mathrm{FdX} 1 \mathrm{X3}$ & -.004 & .057 & -.013 & -.078 & .938 \\
\hline & $\mathrm{FdX} 2 \mathrm{X} 3$ & -.007 & .051 & -.022 & -.135 & .893 \\
\hline
\end{tabular}

a. Dependent Variable: FdY

\section{Sumber: Data Diolah}

Berdasarkan hasil penelitian hipotesis 1 diketahui nilai koefisien parameter sebesar 0.003 dengan tingkat signifikansi sebesar 0.986, sehingga dengan tingkat signifikan diatas 0.05. Yang artinya partisipasi pemakai sistem informasi akuntansi tidak berpengaruh signifikan terhadap efektivitas sistem informasi akuntansi pada LPD di Kecamatan Sukawati.

Hasil penelitian hipotesis 2 diketahui nilai koefisien parameter sebesar 0.452 dengan tingkat signifikansi sebesar 0.002, sehingga dengan tingkat signifikan dibawah 0.05. Yang artinya kecanggihan teknologi informasi berpengaruh positif dan signifikan terhadap efektivitas sistem informasi akuntansi. Hasil penelitian mengandung arti bahwa semakin tinggi kecanggihan teknologi informasi maka akan semakin meningkat efektivitas sistem informasi akuntansi pada LPD di Kecamatan Sukawati.

Hasil penelitian hipotesis 3 diketahui nilai koefisien parameter sebesar -0.004 dengan tingkat signifikansi sebesar 0,938 sehingga dengan tingkat signifikan diatas 0.05 . Hal ini berarti bahwa interaksi partisipasi pemakai sistem informasi akuntansi dengan kemampuan teknik personal $\left(\mathrm{X}_{1} \mathrm{X}_{3}\right)$ tidak berpengaruh signifikan terhadap efektivitas sistem informasi akuntansi (Y). Kemampuan dalam mengoperasikan sistem informasi akuntansi sangat diperlukan untuk mengurangi kesalahan maupun kegagalan dalam pengoperasian suatu sistem sehingga dapat meningkatkan efektivitas sistem informasi akuntansi.

Hasil penelitian hipotesis 4 diketahui nilai koefisien parameter sebesar -0.007 dengan tingkat signifikansi sebesar 0.893 , sehingga dengan tingkat signifikan diatas 0.05 . Hal ini berarti bahwa interaksi kecanggihan teknik personal dengan kemampuan teknik personal 
$\left(\mathrm{X}_{2} \mathrm{X}_{3}\right)$ tidak berpengaruh signifikan terhadap efektivitas sistem informasi akuntansi $(\mathrm{Y})$. Kehadiran teknologi canggih merupakan sumber yang menjadikan sebuah perusahaan memiliki keunggulan kompetitif serta sebagai faktor yang mempengaruhi keberhasilan perusahaan.

\section{SIMPULAN DAN SARAN}

Berdasarkan pembahasan hasil penelitian yang telah diuraikan pada bab sebelumnya, mengenai partisipasi pemakai sistem informasi akuntansi dan kecanggihan teknologi informasi terhadap efektivitas sistem informasi akuntansi dengan kemampuan teknik personal sebagai variabel pemoderasi pada LPD di Kecamatan Sukawati, maka dapat disimpulkan sebagai berikut: (1) Dari hasil penelitian menunjukkan bahwa partisipasi pemakai sistem informasi akuntansi tidak berpengaruh signifikan terhadap efektivitas sistem informasi akuntansi, dengan nilai koefisien parameter sebesar 0.003 dengan signifikansi sebesar $0.986>0.05$, ini berarti $\mathrm{H}_{1}$ ditolak, (2) Dari hasil penelitian menunjukkan bahwa kecanggihan teknologi informasi berpengaruh positif dan signifikan terhadap efektivitas sistem informasi akuntansi, dengan nilai koefisien parameter sebesar 0.452 dengan signifikansi sebesar $0.002<0.05$, ini berarti $\mathrm{H}_{2}$ diterima, (3) Dari hasil penelitian menunjukkan bahwa kemampuan teknik personal tidak mampu memoderasi pengaruh partisipasi pemakai sistem informasi akuntansi terhadap efektivitas sistem informasi akuntansi, dengan nilai koefisien parameter sebesar -0.004 dengan signifikansi sebesar 0.938 $>0.05$, ini berarti $\mathrm{H}_{3}$ ditolak, (4) Dari hasil penelittian menunjukkan bahwa kemampuan teknik personal tidak mampu memoderasi kecanggihan teknologi informasi terhadap efektivitas sistem informasi akuntansi, dengan nilai koefisien parameter sebesar -0.007 dengan signifikansi sebesar $0.893>0.05$, ini berarti $\mathrm{H}_{4}$ ditolak.

Berdasarkan hasil simpulan di atas adapun saran yang dapat diberikan sebagai berikut: (1) LPD di Kecamatan Sukawati diharapkan agar lebih meningkatkan partisipasi pemakai dalam pengembangan sistem informasi akuntansi seperti memberikan kesempatan kepada karyawan untuk mencoba menggunakan sistem informasi akuntansi dan mengungkapkan kelemahan-kelemahan yang didapat oleh setiap karyawan sehingga efektivitas sistem informasi akuntansi akan semakin meningkat, (2) Diharapkan lebih memperhatikan kecanggihan teknologi informasi pada LPD. Penggunaan dan pemeliharaan teknologi informasi agar selalu diperhatikan agar memudahkan perkerjaan karyawan dan 
mengurangi kelemahan-kelemahan yang mungkin terjadi, (3) Berdasarkan kesimpulan diatas diharapkan LPD lebih memperhatihan kemampuan teknik personal karyawan, dengan cara memberikan pelatihan dan masukan pada setiap karyawan agar dapat menguasai penggunaan sistem informasi akuntansi berbasis computer, (4) disarankan bagi peneliti selanjutnya untuk meneliti faktor-faktor lain yang dapat mempengaruhi efektivitas sistem informasi akuntansi sehingga dapat dibandingkan dengan hasil penelitian penulis dengan memperluas atau memperbanyak obyek yang diteliti.

\section{DAFTAR PUSTAKA}

Almilia, Luciana Spica dan Briliantien. 2007. Faktor-faktor yang Mempengaruhi Kinerja Sistem informasi Akuntansi pada Bank Umum Pemerintah di Wilayah Surabaya danSiduarjo. Jurnal Ilmiah. STIE Perbanas. Surabaya.

Ayu Perbarini, N.K dan Juliarsa, G. 2014. Analisis Faktor-Faktor yang Mempengaruhi Kinerja Sistem Informasi Akuntansi pada LPD di Kecamatan Denpasar Utara. EJurnal Akuntansi Universitas Udayana. ISSN.

Ayu Yuni Kurniawati, Ni Putu. 2017. Pengaruh Partisipasi Pemakai Dan Ketidakpastian Tugas pada Kinerja SIA dengan Ukuran Organisasi sebagai Variabel Moderasi pada LPD Di Kecamatan Ubud. E-Jurnal Akuntansi Universitas Udayana. ISSN.

Bodnar, George. H., dan William. S. 2010. Accounting Information System. United States of America: Pearson ducation.

Jogiyanto. 2005, Sistem Teknologi Informasi. Yogyakarta: Andi Offset.

Jogiyanto. 2007. Model Kesuksesan Sistem Teknologi Informasi. Yogyakarta: Andi Publisher.

Jogiyanto. 2009. Sistem Teknologi Informasi. Yogyakarta: Andi Offset.

Krismiaji. 2015, Sistem Informasi Akuntansi, Unit Penerbit, Yogyakarta.

Lisnawati, Ni Kadek. 2017. Pengaruh Personal Capability, Kecanggihan Teknologi Informasi, Perlindungan Sistem Informasi dan Partisipasi Manajemen Terhadap Efektivitas Sistem Informasi Akuntansi pada LPD se-Kecamatan Ubud. E-Jurnal S1 Akuntansi Universitas Pendidikan Ganesha.

Mulyadi. 2016. Sistem Informasi Akuntansi. Edisi ke-4, Cetakan ke-4. Penerbit Salemba Empat, Jakarta

Novia Puspitasari, Ni Wayan. 2017. Pengaruh Keterlibatan Pemakai dan Kemampuan Teknik Personal pada Kinerja Sistem Informasi Akuntansi dengan Pendidikan dan Pelatihan sebagai Variabel Pemoderasi pada LPD Kecamatan Gianyar. Skripsi. Universitas Udayana. Denpasar. 
Oktaviana, Gita. 2017. Pengaruh Kecanggihan Teknologi Informasi, Partisipasi Manajemen dan Pengetahuan Manajer Akuntansi terhadap Efektivitas Sistem Informasi Akuntansi (Studi pada PT Bank Bjb Kota Bandung). Fakultas Ekonomi dan Bisnis Universitas Pasundan Bandung.

Peraturan Gubernur Bali Nomor. 44 Tahun 2017 tentang Peraturan Pelaksanaan Perda Provinsi Bali Nomor 3 Tahun 2017 tentang Lembaga Perkreditan Desa.

Putu Kawiana, I Gede. 2016. "Pedoman Penulisan Usulan Proposal dan Skripsi”. Denpasar. Fakultas Ekonomi Universitas Hindu Indonesia.

Sugiyono. 2017. Metode Penelitian (Pendekatan Kuantitatif, Kualitatif dan R\&D). Bandung:Alfabeta.

Suhardiyah, Martha dan R. Bambang Dwi Waryanto. 2014. Analisis Faktor-Faktor yang Mempengaruhi Kinerja Sistem Informasi. Jurnal Ekonomi Universitas PGRI Adi Buana Surabaya.

Sulastrini, Luh Putu dan Adiputra, I Made Pradana. 2014. Faktor-faktor yang Berpengaruh terhadap Kinerja Sistem Informasi Akuntansi dengan Kompleksitas Tugas sebagai variabel moderasi pada PT. PLN Distribusi Area Bali Utara. E-Jurnal S1 Akuntansi Universitas Pendidikan Ganesha.

Surendran, Priyanka. 2012. Technology Acceptnce Model: A Survey of Literature. International Journal of Business and Social Research (IJBSR), August 2012.

Sutabri, Tata. 2012. Analisis Sistem Informasi. Yogyakarta: Andi Yogya.

Sutarman. 2009. Pengantar Teknologi Informasi. Jakarta: Bumi Aksara.

Terry, Julian and Standing, Craig. 2004. The Value od User Participation in E-commerce System Development. Informing Science Journal 7.

Urquia, Elena. 2011. An Effect off Accounting Information System on Performance Measures: Enrpirical Evidance in Spanish. Journal International of Digital Accounting Research.

Yoga Krisna Aditya, A.A.Ngr. 2018. Pengaruh Kecanggihan Teknologi pada Efektivitas SIA dengan Dukungan Manajemen Puncak dan Kemampuan Teknik Personal sebagi pemoderasi pada Badan Pendapatan Daerah Kota Denpasar. E-Jurnal Akuntansi Universitas Udayana. ISSN. 